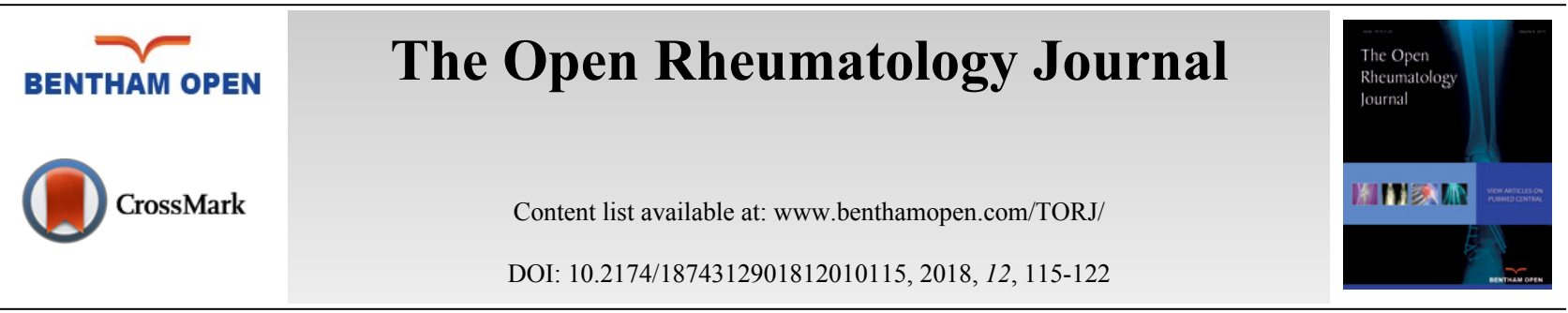

RESEARCH ARTICLE

\title{
MicroRNA155 Expression in Relation to BDCAF Scored Behçet's Disease in an Egyptian Patients' Sample
}

Sally S. Hassouna ${ }^{1, *}$, Manal Y. Tayel ${ }^{1}$, Dalal M. ElKaffash ${ }^{2}$, Ahmed M. Abdelhady ${ }^{3}$ and Eman H. Elsayed $^{1}$

${ }^{I}$ Department of Internal Medicine, Faculty of Medicine, Alexandria University, Alexandria, Egypt

${ }^{2}$ Department of Clinical and Chemical Pathology, Faculty of Medicine, Alexandria University, Alexandria, Egypt

${ }^{3}$ Department of Opthalmology, Faculty of Medicine, Alexandria University, Alexandria, Egypt

Received: April 14, 2018

Revised: May 19, 2018

Accepted: June 22, 2018

Abstract:

Objective:

To discover the possibility of using microRNA155 (miRNA155) expression level as a biomarker of Behçet's Disease (BD) activity or remission.

\section{Methods:}

Thirty BD patients' white blood cells (WBCs) miRNA155 expression was measured and compared to WBCs miRNA155 expression in 15 healthy subjects. Assessment of disease activity was done using Behçet's Disease Current Activity Form (BDCAF).

\section{Results:}

miRNA155 expression significantly decreases with the increase of BD activity scored by BDCAF.

\section{Conclusion:}

Increased miRNA155 may be used as a biomarker of BD remission and thus in the disease follow up. There could be a prospect of treating the disease via microRNA 155 effect enhancement.

Keywords: Behçet's disease, MicroRNA155, BDCAF, Egyptian patients, miRNA155, CD40.

\section{INTRODUCTION}

$\mathrm{BD}$ is a chronic multi-systemic disease characterized by oral ulcers more than 3 times in the year with at least two of the following: genital ulcers, cutaneous manifestations, ophthalmic, neurologic, or rheumatologic presentation [1].

Pathogenesis remains unclear. However, both adaptive and innate immunity play a vital role, and multiple cytokines appeared to be engaged in different pathways of pathogenesis leading to tissue damage [2]. A strong established relation between BD and human leukocytic antigen B51 (HLA-B*51) was evident in the last years [3, 4]. And there was an evidence of CD40 and CD40 ligands on peripheral blood lymphocytes and L- selectin expression on leucocytes of patients with BD $[5,6]$. Some biochemical markers were observed to correlate with BD activity for example, the level of Serum Amyloid A (SAA) which increase with the flares of ocular disease, neurological dysfunction, and the presence of oral ulcers, also it was suggested that increased levels of SAA might denote a thrombotic risk in the disease * Address correspondence to this author at the Department of Internal Medicine, Faculty of Medicine, Alexandria University, Alexandria, Egypt; Tel:
01223433443; E-mails: sallysaadhassouna@gmail.com, s_hassouna151@alexmed.edu.eg 
[7]. Elevated cytokine levels of interleukin 6 (IL-6), interleukin 18 (IL-18), interleukin 8 (IL-8), and interferon $\alpha 2 \mathrm{a}$ (IFN- $\alpha 2 a)$, and low CXCL11 levels were shown in BD. Also, it was observed that a signature of IL-6, and Tumor Necrosis Factor- $\alpha$ (TNF $\alpha$ ) and T helper 17 (Th17) are present as well. This could contribute to uncover the role of cytokines in the appearance of specific clinical features of BD [2].

MiRNAs are endogenous small naturally occurring double stranded (about 21-25 nucleotides) RNAs and were first described by Lee and colleagues in 1993 and were termed microRNAs in 2001. They play important regulatory roles in animals and plants through targeting mRNAs for suppression of translation or cleavage. Researchers have begun to understand that miRNAs influence the output of many protein-coding genes and are considered one of the gene regulatory molecules [8].

MicroRNAs exhibit a variable regulatory function in cell growth and differentiation, and are also associated with different human diseases. Previous research on miRNAs has revealed a new paradigm of gene regulations and pathways involved in the pathogenesis of autoimmune disorders, malignant and heart diseases [9]. Thus human miRNAs are likely to be highly useful with a great promise as biomarkers in diseases' diagnoses, and are targets for disease intervention and attractive for applying new therapies.

\section{AIM OF THE STUDY}

To show the correlation of miRNA155 expression with BD activity scored using BDCAF and the possibility of its usage as a disease activity or remission marker.

\section{SUBJECTS}

Thirty-three BD patients fulfilling the International Study Group diagnostic Criteria of BD [10] were examined.

Seventeen patients had ocular involvement and 16 with non-ocular involvement were recruited from Alexandria university hospital, and out-patient clinics in a cross sectional pattern. Patients with a history of another autoinflammatory or autoimmune disease, other form of vasculitis, hypercoagulable state, malignancy, chemotherapy, radiotherapy or long standing diabetes were excluded. An informed consent was taken from each patient. Three of the non-ocular diseased patients' samples were excluded afterwards for technical errors.

Thirteen BD patients were having positive HLAB51, 18 patients were ANA positive and 7 had positive family history of BD.

Fifteen healthy subjects matched to the patients by age and sex served as the control for miRNA155 expression. Age of the patients ranged between 20 to 55 years old with a mean \pm SD of $38.03 \pm 9.94$ years, and median of 36.5 years. No significant difference between the patients and control subjects. This was applied also for the sex.

Disease activity has been measured using "BDCAF" score depending on the presence or absence of mouth ulcers, genital ulcers erythema nodosum, pustules, arthralgia, arthritis, diarrhea, nausea/ vomiting, headaches, eye inflammation, new central nervous system involvement and new major vessel inflammation, (over the last four weeks before the visit) and accordingly the patients were divided into two groups; a higher disease activity group with a score equals to or more than 4 out of 12, and a lower disease activity group with a score less than 4 . Patients included: are shown in Table $\mathbf{1 .}$

Table 1. Clinical Manifestations in Patients that were Active Through the Four weeks Preceding the Study According to BDCAF. (Each of the Mentioned Items Counts for 1 Point as a Score of Disease Activity).

\begin{tabular}{|c|c|}
\hline Active clinical manifestations & No. \\
\hline Headache & 13 \\
\hline Mouth ulceration & 11 \\
\hline Genital ulceration & 9 \\
\hline Erythema nodosum & 7 \\
\hline Skin Pustules & 6 \\
\hline Joints - Arthralgia & 15 \\
\hline Joints - Arthritis & 6 \\
\hline Nausea/Vomiting/Abdominal pain & 1 \\
\hline Diarrhea + altered/frank blood per rectum & 0 \\
\hline New active eye involvement & 3 \\
\hline
\end{tabular}


(Table 1) contd.....

\begin{tabular}{|c|c|}
\hline Active clinical manifestations & No. \\
\hline New active neurological involvement & 11 \\
\hline New extra-cranial major vessel involvement & \\
\hline
\end{tabular}

Note that some patients had histories of some of these manifestations but were inactive during the study.

\section{METHODOLOGY}

miRNA155 detection was estimated by TaqMan ${ }^{\circledR}$ applied biosystems through a serial of events [11 - 13]. Approval of Ethics Committee was obtained from the Local Ethics Committee of Alexandria University, with a serial number 020850, Chairperson: Dr. Maha Ghanem, IRB No. 0007555-FWA, No. 0018699, on 29-6-2016.

\section{RESULTS}

Our study results showed:

MiRNA155 in the group of highly active BD patients as scored by BDCAF ranged between 0.01 to 1.76 with a mean $\pm \mathrm{SD}=0.48 \pm 0.53$ and a median of 0.38 , while in the lower activity group ranged between 0.01 to 6.56 with a mean $\pm \mathrm{SD}=2.08 \pm 2.43$ and a median of 0.73 and its expression in the control group ranged between 0.11 to 4.8 with a mean $=1.52 \pm 1.27$ and a median of 1.04 . There was a significant difference between the higher activity patients and control group $(p=0.032)$, while there was no significant difference between lower activity patients and control group nor between higher activity and lower activity patients' groups; $p$ values were 1.00 and 0.127 respectively. There was no significant difference in miRNA155 expression in the whole patients group with a range extending from $0.01-6.56$ with a mean $\pm \mathrm{SD}=1.28 \pm 1.91$ and a median 0.44 and control subject where $(p=0.075)$, the comparison is shown in Fig. (1).

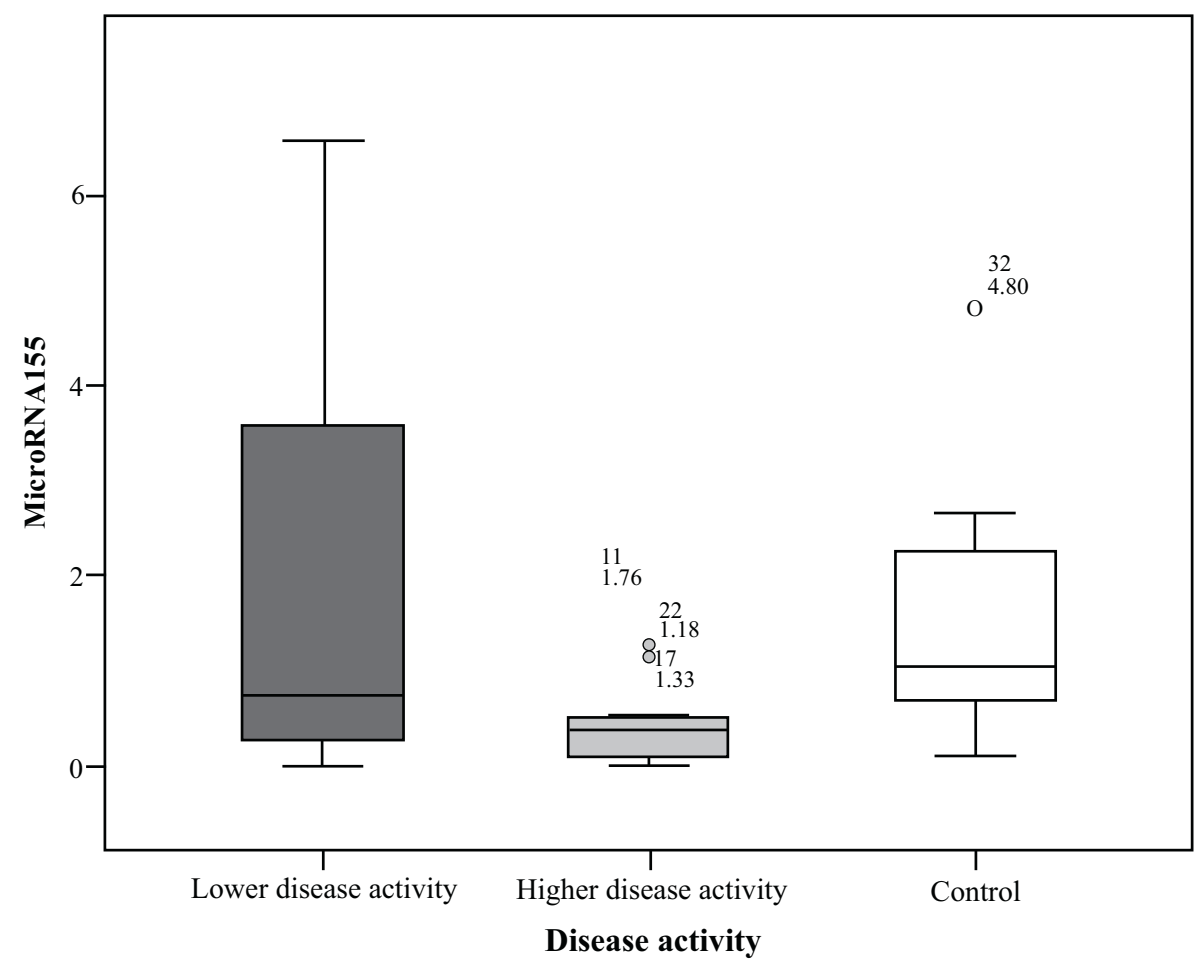

Fig. (1). Comparison between miRNA155 expression in the higher disease activity, lower disease activity and control groups.

Correlation between miRNA155 with BDCAF activity score in BD patients; a significant negative correlation between BDCAF score and miRNA155 expression level in BD patients involved in the study, with rs $=-0.389, p=$ 0.034, this relation is shown in Fig. (2). 


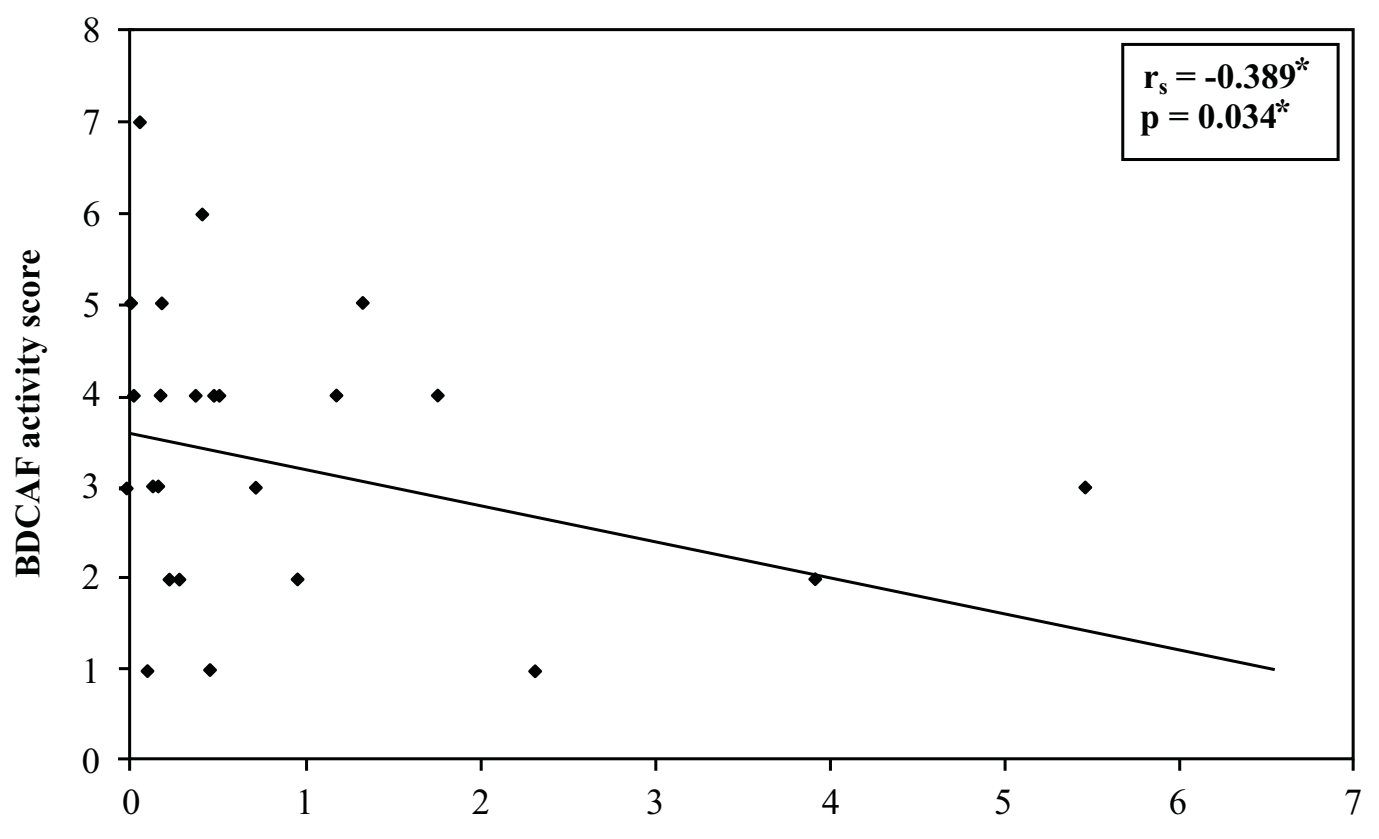

Fig. (2). Correlation between miRNA155 expression in BD patients with activity of the disease scored using BDCAF.

\section{DISCUSSION}

BD is considered a serious syndrome that can lead to severe morbidity and sometimes mortality and unfortunately with no dependent biomarkers to assess activity or remission.

The study was made to show the relation between miRNA155 expression and disease activity.

The results showed a significant inversely proportional relation between miRNA155 expression in the WBCs and disease activity and so the increase of miRNA155 level denotes a disease remission.

This can be explained by knowing that several studies presented miR-155 as a major player in Dendritic Cell (DC) and B cell function and responses as what was discovered in [14 - 16]. Two researches were conducted on mice lacking miR-155 showing aberrant $B$ and $T$ cell functions and defect in antigen presenting cells $[17,18]$.

Also, the increased miRNA155 expression in disease remission may be owing to the fact mentioned in MartinezNunez et al, 2011 study [19] about miRNA 155 implication in the inflammatory pro-Th1/M1 and that miRNA155 may be regulating the macrophages M1/M2 balance by modulation of IL13 effects.

It was said that there is an effect E26 transformation-specific-1 (Ets-1) on increased miRNA155 as Quinn et al., 2014 [20] said, and that Ets-1 is known to be a suppressor of $\mathrm{T}$ helper 17 suppressing the release of pathogenic interleukin 17 (IL17) as appeared in Moisan et al,. 2007 study [21] IL-17 is increased in BD patients and there is a further increase with activity, ocular, and neurological involvement as what was said in Lopalco 2017 et al. [22], and Dina et al., 2015 [23].

Although our study included a more wide disease clinical spectrum, this finding of decreased miRNA155 with increased disease activity was shown before in ocular BD through Zhou et al., 2012 [24] which stated that miRNA155 expression levels in PBMCs and DCs was decreased in BD patients suffering from active uveitis and overexpression of miRNA155 in DCs increased the inhibitory interleukin 10 (Il 10) and decreased Il6 and Interleukin 1B (Il1B) expression which are pro-inflammatory cytokines which may contribute to disease flare. it was shown in some studies, such as Lopalco et al., 2015, that there is an important role Il6 in BD pathogenesis [2].

Some other studies showed an opposite result to ours and that miRNA155 expression is increased in BD activity, as the study of Tili et al., 2007 which found that miR-155 is a potent pro-inflammatory microRNA and stated that E $\mu$ transgenic miR-155 mice have excessive uncontrolled inflammatory responses, giving excessive Tumor Necrosis Factor Alpha (TNF $\alpha)$ and septic shock hypersensitivity [25].

Other researches showed that miR-155 targeting Ets-1 regulates Th17 response and suppression of miR-155 
decreases pathogenic IL-17-expressing T cells amount as in Na et al., 2016 study [26].

Also, Ryan et al. 2011 study found that miRNA155 fosters autoimmunity through inflammatory $\mathrm{T}$ cells development [27]. Also, it was mentioned in Rajasaki et al. 2017 that Resolvin D1, through inhibiting miRNA155, decreases experimental corneal immunopathology inflammation [28]. And in Zheng et al. 2012 and Chinenov et al., 2014, it was shown that glucocorticoids are effective in inflammation termination, mediated by miR-155 expression inhibition in a nuclear factor kappa-light-chain-enhancer of activated B cells and glucocorticoids receptor dependent way $[29,30]$.

The findings in some studies are consistent with ours and some are not, this is may be owing to different ethnicities, different disease activity in the patients in one study from another, also some researches which had the same results of ours or the opposite were depending only on animal studies and we should take this into consideration. Also, BDCAF scoring is almost subjective, depending on patients' own words in many instances and this may be not so much accurate.

And thus miRNA155 role in BD pathogenesis is still controversial.

\section{CONCLUSION}

Studies on miRNA155 expression levels in active BD disease should be done on a large base to know if there is a cut off to say the disease is active or in remission and for confirmation of the possibility of its usage as a biomarker for follow up of the patient, and to do studies for Ets-1 enhancement or other means of miRNA155 promotion to see the effect on disease progression and potential of this for disease treatment.

\section{ETHICS APPROVAL AND CONSENT TO PARTICIPATE}

Approval of Ethics Committee was obtained from the Local Ethics Committee of Alexandria University, with a serial number 020850, Chairperson: Dr. Maha Ghanem, IRB No. 0007555-FWA, No. 0018699, on 29-6-2016.

\section{HUMAN AND ANIMAL RIGHTS}

No Animals were used in this research. All human research procedures followed were in accordance with the ethical standards of the committee responsible for human experimentation (institutional and national), and with the Helsinki Declaration of 1975, as revised in 2013.

\section{CONSENT FOR PUBLICATION}

Written informed consent was taken from all the patients when they were enrolled.

\section{CONFLICT OF INTEREST}

The authors declare no conflict of interest, financial or otherwise.

\section{ACKNOWLEDGEMENTS}

It is an onus to thank, All the patients and healthy volunteers who participated in this work, Dr. Eman Tayae, the lecturer of Clinical pathology at Alexandria University for her experience and cooperation in lab work, Dr. Rowayda M. Amin, the assistant lecturer of Opthalmology department at Alexandria University for her help in recruitment of many patients from the ophthalmology out-patient clinic and for her solicitude and care. Dr. Alya Elkayal and Dr. Asmaa Nasr, the clinical pathology residents for helping in doing many steps in the procedure, and the lab technicians for being keen and meticulous in their work. 


\section{APPENDAGES}

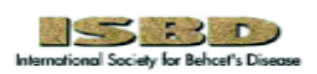

Date:

Centre:

Country:

Clinician:

\section{BEHÇET'S DISEASE CURRENT} ACTIVITY FORM 2006

Name:

Telephone

Address:
Sex: MrF

Date of birth

All scoring depends on the symptoms present over the 4 weeks prior to assessment.
Only clinical features that the cllnlclan feels are due to Behcet's Disease should be

PATIENT'S PERCEPTION OF DISEASE ACTIVITY

"Thlinking about your Behçet's dilsease only, which of these faces expresses how you have been feelling over
the last four veeks? "(Tlck one face)

HEADACHE, MOUTH ULCERS, GENITAL ULCERS, SKIN LESIONS, JOINT INVOLVEMENT AND HEADACHE, MOUTH ULCERS, GENT
GASTROINTESTINAL SYMPTOMS

Ask the patient the following questions and fill in the related boxes "Over the past 4 weeks have you had?"

\begin{tabular}{|c|c|c|c|c|c|c|}
\hline & (plee & ase tick o & ne box per: & & & \\
\hline & & not at all & $\begin{array}{c}\text { Prosent } \\
\text { for up to } 4 \\
\text { wooks }\end{array}$ & & & \\
\hline $\begin{array}{l}\text { Headache } \\
\text { Mouth Ullcoration }\end{array}$ & & & & & & \\
\hline $\begin{array}{l}\text { Gonital Ulcoration } \\
\text { Erythema }\end{array}$ & & & & & & \\
\hline $\begin{array}{l}\text { Erytherma } \\
\text { Skin Pustules }\end{array}$ & & & & & & \\
\hline $\begin{array}{l}\text { Joints - Arthralgia } \\
\text { Joints - Arthritis }\end{array}$ & & & & & & \\
\hline $\begin{array}{l}\text { Joints - Arthritis } \\
\text { Nausea/vomiting/abdominal pain }\end{array}$ & & & & & & \\
\hline $\begin{array}{l}\text { Nausea/vorniting/abdominal pain } \\
\text { Diamhoea+altered/frank blood per }\end{array}$ & turn & & & & & \\
\hline $\begin{array}{l}\text { EYE INVOLVEMENT } \\
\text { (Ask questions below) }\end{array}$ & & & & & & \\
\hline & & & & sploe & ralo) & \\
\hline "Over the last 4 weeks have you & & & Righ & & & \\
\hline $\begin{array}{l}\text { "Over the last } 4 \text { weeks have you } \\
\text { had?" }\end{array}$ & $\begin{array}{l}\text { a red eye } \\
\text { a painful eye } \\
\text { blurred or reduced vision }\end{array}$ & & $\begin{array}{l}\text { No } \\
\text { No } \\
\text { No }\end{array}$ & $\begin{array}{l}\text { Yes } \\
\text { Yes } \\
\text { Yes }\end{array}$ & $\begin{array}{l}\text { No } \\
\text { No } \\
\text { No }\end{array}$ & $\begin{array}{l}\text { Yes: } \\
\text { Yes } \\
\text { Yes }\end{array}$ \\
\hline $\begin{array}{l}\text { If any of the above is present: "Is } \\
\text { (circle the corroct answer) }\end{array}$ & ils new"? & & & No & Yos & \\
\hline
\end{tabular}

NERVOUS SYSTEM INVOLVEMENT (include intracranial vascular disease)

New Symptoms in nervous system and major vessel involvement are defined as those not previously documented or reported by the patient

Over the last 4 weeks have you had any of the following?

blackouts

difficulty with hearing

blurring offdouble vision

weakness/loss of feeling of face

weakness/loss of feeling of arm

weaknessioss of feeling of le

memory loss

Is there any evidence of new active nervous system involvement?

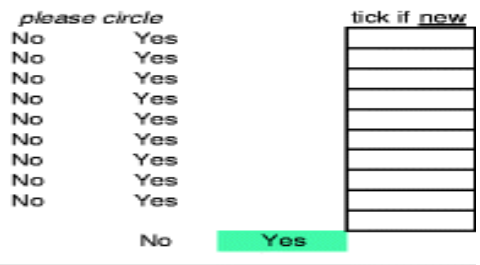

MAJOR VESSEL INVOLVEMENT(exclude intracranial vascular disease) (Ask question below)

"Over the last 4 wreeks have you had any of the following?"

had chest pain

had breathlessness

had pain/swelling/discolouration of the face

had pain/swelling/discolouration of the arm

had pain/swelling/discolouration of the leg

Is there evidence of new active major vessel inflammation?

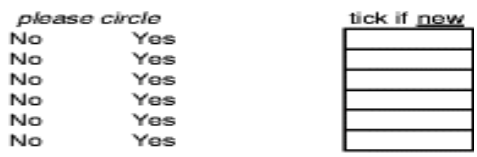

CLINICIAN'S OVERALL PERCEPTION OF DISEASE ACTIVITY

Tick one face that expresses how you feet the patient's

Ticoase has been over the last 4 weeks.

$\Theta \odot \Theta \Theta \Theta \theta \odot$

BEHÇET'S DISEASE ACTIVITY INDEX

Add up all the scores which are highlighted in blue ffront page iterns, one tick = score of 1 on index, all other items
score 'yes" $=1$. You should now have a score out of 12 which is the patient's Behcet's Disease Activity Index Score.

SCORE

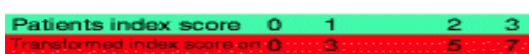

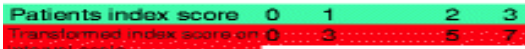

Explanation to doctor completing the form:

Buniversity of Leeds UK

06.03 .06

1. Use your clinical judgment recording only those teatures you believe are due to Behcet's disease.

2. Please explain to the patient the meaning of the words used, if necessary.

3. If there is pain in a joint (whether or not there is swelling etc) score 'arthralgia'

4. If there is swelling or inflammation of a joint score 'arthritis'. Thus you can score 'arthralgia" and "arthritis'.

5. The form concerns the impaiments relating to Disease Activity. It is produced by Rasch analysis and

is psychometrically robust. It is not measuring the impact of the disease activity. 


\section{REFERENCES}

[1] Sakane T, Takeno M, Suzuki N, Inaba G. Behçet's disease. N Engl J Med 1999; 341(17): $1284-91$. [http://dx.doi.org/10.1056/NEJM199910213411707] [PMID: 10528040]

[2] Lopalco G, Lucherini OM, Vitale A, Talarico R, Lopalco A, Galeazzi M, et al. Putative role of serum amyloid-A and proinflammatory cytokines as biomarkers for behcet's disease. 2015

[3] Petrushkin H, Hasan MS, Stanford MR, Fortune F, Wallace GRBD. Behçet's disease: Do natural killer cells play a significant role? Front Immunol 2015; 6: 134. [http://dx.doi.org/10.3389/fimmu.2015.00134] [PMID: 25852697]

[4] Zierhut M, Mizuki N, Ohno S, et al. Immunology and functional genomics of Behçet’s disease. Cell Mol Life Sci 2003; 60(9): $1903-22$. [http://dx.doi.org/10.1007/s00018-003-2333-3] [PMID: 14523551]

[5] Assaad-Khalil S, Abou Seif M, Elkaffash D. CD40 and CD40 ligands on peripheral blood lymphocytes in BD disease.

[6] Assaad-Khalil SH, Abou-Seif M, Youssef I, Farahat N. L-selectin expression on leukocytes of patients with Behçet's disease. Adv Exp Med Biol 2003; 528: 273-8. [http://dx.doi.org/10.1007/0-306-48382-3_55] [PMID: 12918706]

[7] Vitale A, Rigante D, Lopalco G, et al. Serum amyloid-A in Behçet's disease. Clin Rheumatol 2014; 33(8): $1165-7$. [http://dx.doi.org/10.1007/s10067-014-2555-9] [PMID: 24659331]

[8] Lee RC, Feinbaum RL, Ambros V. The C. elegans heterochronic gene lin-4 encodes small RNAs with antisense complementarity to lin-14. Cell 1993; 75(5): 843-54. [http://dx.doi.org/10.1016/0092-8674(93)90529-Y] [PMID: 8252621]

[9] O'Connell RM, Rao DS, Chaudhuri AA, Baltimore D. Physiological and pathological roles for microRNAs in the immune system. Nat Rev Immunol 2010; 10(2): 111-22. [http://dx.doi.org/10.1038/nri2708] [PMID: 20098459]

[10] Eye examination Available from: http:/www.mayoclinic.com/health/eye-exam/MY00245

[11] Applied biosystems by life Technologis TaqMan ${ }^{\circledR}$ MicroRNA Assays (Protocol) Available from: https://genome.med.harvard.edu/ documents/qpcr/ microRNATaqManAssayProtocol.pdf

[12] Applied biosystems by life Technologis TaqMan® Universal PCR Master Mix (Protocol) Available from: https://assets.thermofisher.com/ TFS-Assets/LSG/manuals/4304449_TaqManPCRMM_UG.pdf

[13] Applied biosystems by life Technologis TaqMan ${ }^{\circledR}$ Small RNA Assays TaqMan ${ }^{\circledR}$ MicroRNA Assays TaqMan ${ }^{\circledR}$ siRNA Assays Custom TaqMan ${ }^{\circledR}$ Small RNA Assays (Protocol) Available from: https://tools.thermofisher.com/content/sfs/manuals/cms_042167.pdf

[14] Martinez-Nunez RT, Louafi F, Friedmann PS, Sanchez-Elsner T. MicroRNA-155 modulates the pathogen binding ability of dendritic cells (DCs) by down-regulation of DC-specific intercellular adhesion molecule-3 grabbing non-integrin (DC-SIGN). J Biol Chem 2009; 284(24): $16334-42$. [http://dx.doi.org/10.1074/jbc.M109.011601] [PMID: 19386588]

[15] Vigorito E, Perks KL, Abreu-Goodger C, et al. microRNA-155 regulates the generation of immunoglobulin class-switched plasma cells. Immunity 2007; 27(6): 847-59.

[http://dx.doi.org/10.1016/j.immuni.2007.10.009] [PMID: 18055230]

[16] Ceppi M, Pereira PM, Dunand-Sauthier I, et al. MicroRNA-155 modulates the interleukin-1 signaling pathway in activated human monocytederived dendritic cells. Proc Natl Acad Sci USA 2009; 106(8): 2735-40.

[http://dx.doi.org/10.1073/pnas.0811073106] [PMID: 19193853]

[17] Rodriguez A, Vigorito E, Clare S, et al. Requirement of bic/microRNA-155 for normal immune function. Science 2007; 316(5824): 608-11. [http://dx.doi.org/10.1126/science.1139253] [PMID: 17463290]

[18] Thai TH, Calado DP, Casola S, et al. Regulation of the germinal center response by microRNA-155. Science 2007; 316(5824): 604-8. [http://dx.doi.org/10.1126/science.1141229] [PMID: 17463289]

[19] Martinez-Nunez RT, Louafi F, Sanchez-Elsner T. The interleukin 13 (IL-13) pathway in human macrophages is modulated by microRNA-155 via direct targeting of interleukin 13 receptor alpha1 (IL13Ralpha1). J Biol Chem 2011; 286(3): 1786-94. [http://dx.doi.org/10.1074/jbc.M110.169367] [PMID: 21097505]

[20] Quinn SR, Mangan NE, Caffrey BE, et al. The role of Ets2 transcription factor in the induction of microRNA-155 (miR-155) by lipopolysaccharide and its targeting by interleukin-10. J Biol Chem 2014; 289(7): 4316-25. [http://dx.doi.org/10.1074/jbc.M113.522730] [PMID: 24362029]

[21] Moisan J, Grenningloh R, Bettelli E, Oukka M, Ho IC. Ets-1 is a negative regulator of Th17 differentiation. J Exp Med 2007; 204(12): $2825-35$.

[http://dx.doi.org/10.1084/jem.20070994] [PMID: 17967903]

[22] Lopalco G, Lucherini OM, Lopalco A, et al. Cytokine signatures in mucocutaneous and ocular behçet's disease. Front Immunol 2017; 8: 200. [http://dx.doi.org/10.3389/fimmu.2017.00200] [PMID: 28289419]

[23] Al-Zifzaf DS, Mokbel AN, Abdelaziz DM. Interleukin-17 in Behçet's disease: Relation with clinical picture and disease activity. 2015; 42: pp. 
(1)34-8.

[24] Zhou Q, Xiao X, Wang C, et al. Decreased microRNA-155 expression in ocular Behcet's disease but not in Vogt Koyanagi Harada syndrome. Invest Ophthalmol Vis Sci 2012; 53(9): 5665-74. [http://dx.doi.org/10.1167/iovs.12-9832] [PMID: 22815348]

[25] Tili E, Michaille JJ, Cimino A, et al. Modulation of miR-155 and miR-125b levels following lipopolysaccharide/TNF- $\alpha$ stimulation and their possible roles in regulating the response to endotoxin shock. J Immunol 2007; 179(8): 5082-9. [http://dx.doi.org/10.4049/jimmunol.179.8.5082] [PMID: 17911593]

[26] Na SY. Park MJ1, Park S, Lee ES. MicroRNA-155 regulates the Th17 immune response by targeting Ets-1 in BD disease. Clin Exp Rheumatol 2016; 34: S56-s63. [PMID: 27156371]

[27] O'Connell RM, Kahn D, Gibson WS, et al. MicroRNA-155 promotes autoimmune inflammation by enhancing inflammatory T cell development. Immunity 2010; 33(4): 607-19.

[http://dx.doi.org/10.1016/j.immuni.2010.09.009] [PMID: 20888269]

[28] Rajasagi NK, Bhela S, Varanasi SK, Rouse BT. Frontline Science: Aspirin-triggered resolvin D1 controls herpes simplex virus-induced corneal immunopathology. J Leukoc Biol 2017; 102(5): 1159-71. [http://dx.doi.org/10.1189/jlb.3HI1216-511RR] [PMID: 28584076]

[29] Zheng Y, Xiong S, Jiang P, et al. Glucocorticoids inhibit lipopolysaccharide-mediated inflammatory response by downregulating microRNA-155: A novel anti-inflammation mechanism. Free Radic Biol Med 2012; 52(8): 1307-17. [http://dx.doi.org/10.1016/j.freeradbiomed.2012.01.031] [PMID: 22326887]

[30] Chinenov Y, Coppo M, Gupte R, Sacta MA, Rogatsky I. Glucocorticoid receptor coordinates transcription factor-dominated regulatory network in macrophages. BMC Genomics 2014; $15: 656$.

[http://dx.doi.org/10.1186/1471-2164-15-656] [PMID: 25099603]

(C) 2018 Hassouna et al.

This is an open access article distributed under the terms of the Creative Commons Attribution 4.0 International Public License (CC-BY 4.0), a copy of which is available at: (https://creativecommons.org/licenses/by/4.0/legalcode). This license permits unrestricted use, distribution, and reproduction in any medium, provided the original author and source are credited. 